\title{
The V-model of service quality: an African case study
}

\author{
Grafton Whyte
}

HP-GSB, Namibia University of Science and Technology, Windhoek, Namibia, and

\author{
Andy Bytheway \\ University of the Western Cape, Bellville, South Africa
}

\begin{abstract}
Purpose - This paper aims to introduce and demonstrate a new model for service quality that separates out the measurement of service quality in ways grounded in psychological theory and methodological symmetry. Design/methodology/approach - A review of experience in service quality management suggests that new approaches are needed. By seeking a way of managing service at different levels, with symmetry between data collection and data analysis, a model is presented that has more potential applicability and flexibility than is found in traditional models.

Findings - A national study in Namibia, Africa provided data that successfully demonstrate the method of working and illustrate the contextual, analytical and data management issues and the reporting potential out of complex service management data.

Research limitations/implications - This new approach to the design of service quality measurement and assessment extends the capability that is generally found in other existing approaches. It provides a new foundation for further research into complex patterns of service success and that will establish more clearly the inter-dependencies between service encounters, service attributes and service measures at the survey item level.

Practical implications - Studies of multiple service sectors and multiple service recipient groups can now gather and manage large complex data sets and analyse and report that data in ways appropriate to the needs of different stakeholders.

Social implications - In any context where service quality is a socio-economic or development issue, it is now possible to take a more careful and nuanced approach to the collection and aggregation of data, which will inform policy makers and other stakeholder groups at the national or regional level.

Originality/value - This new model addresses a range of problems that have been reported with historical approaches such as SERVQUAL and related methods of working. It also provides foundations for new designs for large-scale service management data collection, organisation and analysis.
\end{abstract}

Keywords Service management, Personal construct theory, Service quality, Repertory grid, V-Model of service quality

Paper type Research paper

\section{Introduction}

Opportunities in Africa

Africa has been identified as a continent with major economic opportunities (Fick, 2007). Despite the present difficulties faced by international businesses in Africa (Baobab, 2013), the longer term trends are becoming clear, and they are attractive to investors. For example, the retailing expansion that serves the emerging needs of the new middle classes in Africa

The authors would like to acknowledge the helpful comments and contributions of the anonymous reviewers, and the ongoing assistance provided by the editors.

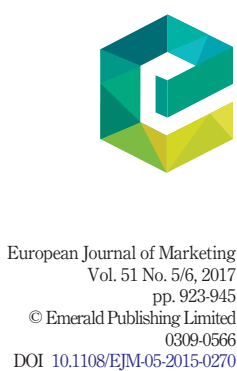

Received 13 May 2015 Revised 21 November 2015 23 February 2016 9 May 2016 27 August 2016 Accepted 19September 2016 
draws together retailing groups, banks, logisticians and other specialists (Dakora and Bytheway, 2011). However, where international businesses come face to face with unfamiliar cultures in Africa - being familiar with only European or North American practices - a range of diverse difficulties emerge that derive from cultural differences. For example, if the number of languages in a country can be taken as a proxy for the number of cultures, in South Africa, there are 11 official languages, and Namibia has 13; in Nigeria, there are over 500 additional indigenous languages as well as the five principal languages including English.

How does one develop and manage new markets in a situation like this? "African solutions to African problems' is a maxim that was popularised by Thabo Mbeki, the second President of the democratic Republic of South Africa” (Mulemfo, 2000). This was because of presumed differences between "Western" and "African" thinking, and because Africa in general was (and still is) suffering from inadequate delivery of basic services such as housing, health care, education and essential utilities. This inadequacy contrasts awkwardly with the burgeoning provision of developed-country services to the new African middle classes.

\section{A lack of service management in Namibia}

The causes of this lack of delivery are many and complex, but one significant factor impacting on this problem is an inadequate understanding (among service providers) of what it means to provide good service, recognising that there are differences between the needs and expectations of different recipient groups.

A rare example of a study of local government service delivery, based on work in two remote communities in Namibia, found that:

Limited planning capacity, combined with lack of relevant data and statistics represent major constraints for the design and implementation of council plans in both Ondangwa and Outapi. Since no socio-economic profiles are yet available in the two councils, there is limited knowledge about (citizen) needs (Fjeldstad et al., 2005, p. 11).

The absence of information about the demographics in these communities, and the clear need for better local government planning, reveals critical challenges to service management:

In both councils a mismatch between citizens' dissatisfaction with service delivery and their willingness to pay for the services was observed (Fjeldstad et al., 2005, p. 12).

There are strong indications that such communities need to be seen by local government as customers, who expect to receive value for money, as is the case in any business and in commercial activity involving the new African middle classes. With such shortfalls in the provision of local services to the poor, what chance is there to achieve an equitable balance in service delivery, as economic activity continues to extend?

In Namibia, there is economic advancement, but little evidence that the quality of service delivery has changed in the past 10 years. There has been no academic endeavour to study and understand the potential for better service management that recognises the differences in need and expectations across different groups. It is in this context that the Harold Pupkewitz Graduate School of Business in Namibia launched a five-year project to transform the national service culture in Namibia and thereby positively influence the delivery of basic services in the country. This is intended to help make the country a better place to do business, and although the study is based in Namibia, it is hoped to stimulate new thinking about service management in other contexts, where similar differences exist and where cultures clash. 
Progressive businesses in developed economies establish long-term relationships with their customers, embracing concepts such as customer retention, customer loyalty and customer experience. If long-term relationships are to be achieved in a developing country where service management is weak, then there needs to be a reliable way to measure change in customer service. In service management that debate has, for the past 30 years, been dominated by theories of service quality - but there is evidence that these theories still fall short of what is required, especially in a multicultural, multi-faceted, developing society such as Namibia (Ladhari, 2009, provides copious evidence of different opinions about service management). Further, the availability of information technology and network connectedness provides opportunities to collect more data about service management, and to analyse it more effectively. It is a recurring theme that local circumstances must be taken into account in planning the collection and analysis of service performance data.

The purpose of this paper is therefore twofold:

(1) to present a new model, demonstrating the measurement of service quality in ways grounded in psychological theory and methodological symmetry; and

(2) to demonstrate the use of the new model in a large-scale, multi-sector survey of public and business organisations in Namibia that embraced significant differences in needs and expectations.

The paper is therefore structured as follows:

- a review the literature concerning service quality, acknowledging SERVQUAL as the dominant theory but highlighting other approaches and summarising some concerns about SERVQUAL;

- a reflection on the recurring need to adapt service quality measurement to account for particular circumstances;

- introduction of the V-model of service quality (VMSQ) as an approach that provides adaptability and flexibility in large multi-sector assessments of service quality; and

- an explanation of the deployment of VMSQ, illustrated using a single large multi-sector study of service management in Namibia, focusing on attribute selection, data collection, data analysis, reporting of results and service comparisons.

The paper concludes with a discussion of the benefits of the VMSQ approach, the contribution that is made, and the implications for practice and research.

\section{Literature review}

\section{SERVQUAL blazes a trail: the emergence of service quality management}

Since the mid-1980s, there has been a strong and continuous stream of research defining and measuring service quality. Most work has been dominated by the ideas of Parasuraman et al. (1985), and the survey instrument that is generally referred to as SERVQUAL. Their theory is based on the idea that service quality is essentially a comparison between customers' expectations of a service and their perceptions of what was delivered. In early SERVQUAL thinking, there is a core set of ten "dimensions[1]" that define the service quality relationship across all services, based on interviews and focus groups across four industries (Parasuraman et al, 1985). Subsequent work using factor analysis subsumed the ten into just five dimensions, namely, reliability, responsiveness, assurance, empathy and tangibles, assessed using a 22-item scale (Parasuraman et al., 1988). 
EJM

$51,5 / 6$

926

\section{A variety of approaches to service quality management}

More than 300 research articles feature applications or adaptations of the SERVQUAL model, and other lesser-known attempts at measuring service quality, including work in specific sectors such as leisure, tourism and hospitality (Augustyn and Seakhoa-King, 2004); higher education (Abdullah, 2006); internal IT services (Carr, 2007); social enterprises (Al-allak and Ali Bekhet, 2011); IT research into technology adoption and continuance; and functional affordance (Tate and Evermann, 2010).

In an effort to understand the circumstances of service management and measurement, a large study by Stacey and Bick (2014) focused on the idea of "service encounters", using a modified critical incident technique applied in interviews with over 800 respondents. They subsequently identified a taxonomy of 12 key service encounters (KSEs) which they argue are sufficient to define the service experience for most customers: these KSEs not only bear some comparison with the ten dimensions of SERVQUAL but also indicate different issues that were found to be important; they are just one example of very many variations on the same kinds of result.

Although many examples are based in a single sector, or segment, of a country or an industry, the question arises as to what will work in a situation where service recipients divide into different groups with quite different needs and expectations, leading to a complex portfolio of services, relating in a complex way to the many groups? Further, in the modern world, there is the possibility of gathering more data, at a more detailed level, captured automatically by embedded systems.

\section{The availability of copious data}

Taking the opportunity to collect service management data in new ways, for example using the social Web (and soon, the Internet of Things) will be a real challenge for managers in general and for service management specialists in particular. The combination of the internet and marketing is seen as something completely new (Jara et al., 2012); it is expected that modes of business operation will continue to be significantly changed in the future by the Internet of Things (Wei and Liping, 2013); near field communication allows immediate connection of customer and retailer devices, so that there are no limits to the volume and kind of data that can be collected (Ceipidor et al., 2011).

But this is beyond the scope of the present study. What is certain is that the organisation and management of data about service management is going to be a challenge. No longer will it be sufficient to undertake a snapshot study of one sector, or one customer group - there will be data that will enable the relationships between service providers, service recipients, their devices and the actual services, to be analysed in ways that we can barely imagine at the present time (Xu, 2011).

\section{Need for a new model}

These concerns, taken with the wider evidence that is found in the literature, hint strongly at the need to understand service management at three different levels:

(1) First, to recognise the variety of circumstances that might have to be dealt with, even with just a single service under management. Service encounters will be seen differently by different kinds of recipient having different needs, different expectations and different cultural precepts.

(2) Second, to recognise that the dependencies and relationships between the attributes of service quality are complex and not necessarily reducible to a single set of attributes there will be patterns of service quality that display different combinations of attributes, measured at different levels. 
(3) Third, to take a careful approach to service quality measurement, making the best use of available information technologies and information management techniques.

\section{V-model of service quality: a new model for service quality management}

The VMSQ has been developed to separate out and deal with the three levels of concern:

(1) the variety of circumstances;

(2) the relationships between attributes; and

(3) the base service data that is collected.

It shows how the treatment of service management at these three levels can be seen as a "V": an analysis must start with the context, drill "down" into the detail and then come back "up" to inform an understanding of the context that enables appropriate management actions (Figure 2). This arrangement of ideas provides symmetry in the approach to analysis at the same time that the separation between the three different levels of working is maintained; it also acknowledges the need to undertake appropriate design, before operationalisation of the design in an actual intervention.

The sections that follow briefly discuss issues of theory building and operationalisation and then introduce the VMSQ management.

The nature of an intervention: theory building and operationalisation

Much of the difficulty that has been reported centres around the need to adapt as well as adopt existing approaches to service management. The recommendation to fully understand the context and incorporate specific needs into the design of an intervention is commonly found, and it makes clear that there has to be a period of design or theory building before committing to the operationalisation of a full study.

Three examples begin to make this clear:

- The Parasuraman Berry and Zeithaml (PBZ) SERVQUAL model, which developed a theory over a period, ultimately reducing ten attributes (dimensions) to just five, operationalised by 22 survey items (Zeithaml et al., 2002).

- A study of information systems service management by the author, which derived 21 attributes by means of personal construct theory (PCT), introduced a degree of selectivity, and introduced rigour by means of an independent measure of success (Whyte, 1994).

- The new model, which introduces flexibility in the operationalisation of measurement and analysis at three different levels, based on any theoretical design that might be taken as a starting point.

Figure 1 highlights some of the features of theory building and operationalisation.

In theory building, there are questions to be addressed:

Q1. What is the context, and what kinds of services are provided?

Q2. What different groupings of respondents are there, and how can they be segmented?

Q3. Given all the previous reported experience with service quality measurement, which attributes might actually be applicable in a particular context?

Then, in operationalising a theoretical design, there are three further questions to be addressed: 
EJM

$51,5 / 6$

\section{8}

Figure 1.

Building and operationalising theory
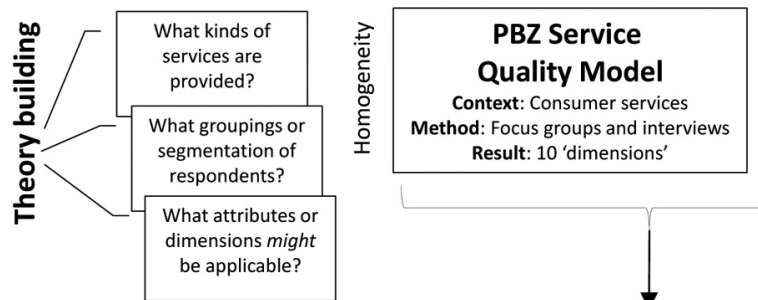

\section{Systems Service}

Quality Model

Context: Information system services

Method: Personal constructs, RepGrid

Result: 21 'information system attributes'
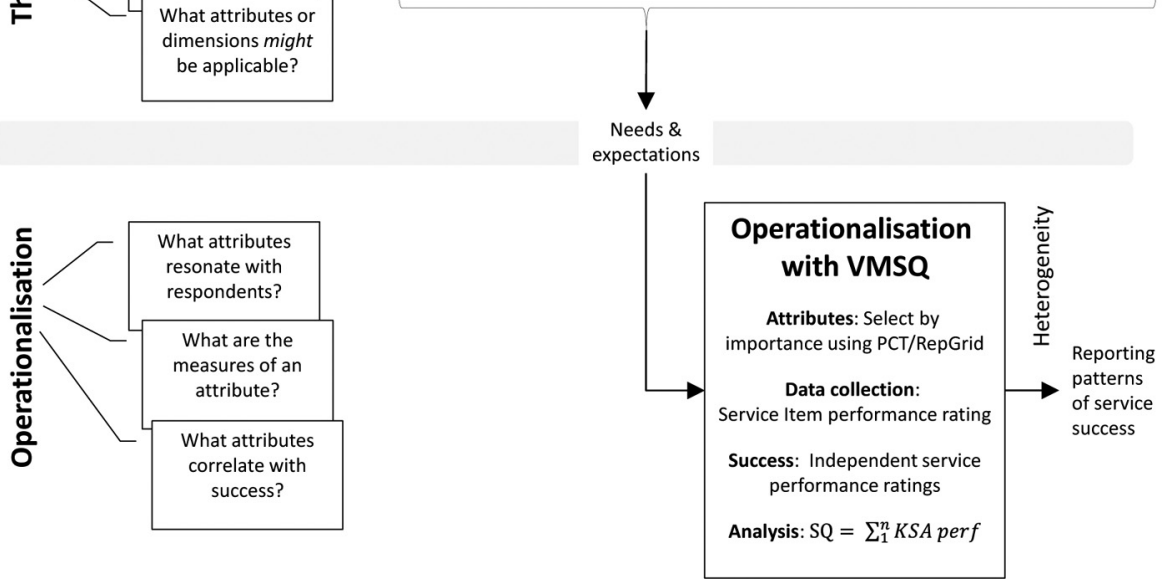

Q4. Of the attributes that might be applicable, which of them resonate with respondents, or are otherwise found to be applicable?

Q5. What actual data can be elicited that provides measurement of those chosen attributes, or positions them on a "dimension" (using the PBZ terminology)?

Q6. Most importantly, which attributes actually correlate with success?

For the purposes of this paper, the figure chooses to highlight the PBZ service quality model (Parasuraman et al., 1985) and a systems service quality model (Whyte, 1994) as examples of theory building. There are of course many other examples available. Here, we have one PBZ - that is based on consumer services, developed from focus groups and interviews, and has (in its initial presentation) ten "dimensions"; the other - the systems service quality model - introduces flexibility, was developed using psychological theory and has 21 attributes that are statistically shown to correlate with success. Either of these two models could be taken as a starting point, so as to provide an understanding of needs and expectations of respondent groups that guides the operationalisation of measurement in the VMSQ.

The idea of the " $V$ " model

The idea of a "V" model is not new. An example can be found in the management of information system development (Bytheway, 2015, p. 73), which is similarly concerned with high-level issues (business analysis), intermediate issues (system design) and low-level issues (program coding), and with testing at each of these levels. The design of a service management intervention shares these issues of levelling: The scope of an intervention has to be decided and the participants have to be identified - the "service" level; the choice of attributes has to be made - the "attribute" level; the statistical analysis of the data has to be designed based on attributes that are applicable in the context of the intervention - the "item" 
level. Data have to be collected and then analysed with appropriate care, at each of these three levels. The VMSQ is constructed so as to reflect this (Figure 2).

\section{Features of the V-model of service quality model}

The features of the model explained in the notes that follow:

(1) V1: Service quality measurement starts and ends in real-world scenarios of service, and the specific service groups of people, industries and business processes that display the patterns of service management need and opportunity that we seek.

(2) V2: Comparing the left and the right-hand sides of the model, there is symmetry between the data collection and analysis stages. There are no "orphan" stages and the linkages are clear and different: mean statistics (at the lower level), correlation analysis (in the middle) and segmentation for development of new policies and strategies (at the top).

(3) V3: The pivotal point in the model is the independent rating of a service given by a respondent, the sum of all such ratings being used during the analysis that follows.

(4) V4: On both sides, each stage of the model involves some form of progressive filtering (or funnelling). During data collection, the respondent is required to:

- select the most important service encounter;

- select the most important service attributes;

- rate the performance of the service for those attributes only; and

- (finally) rate the quality of the whole service encounter, independently.

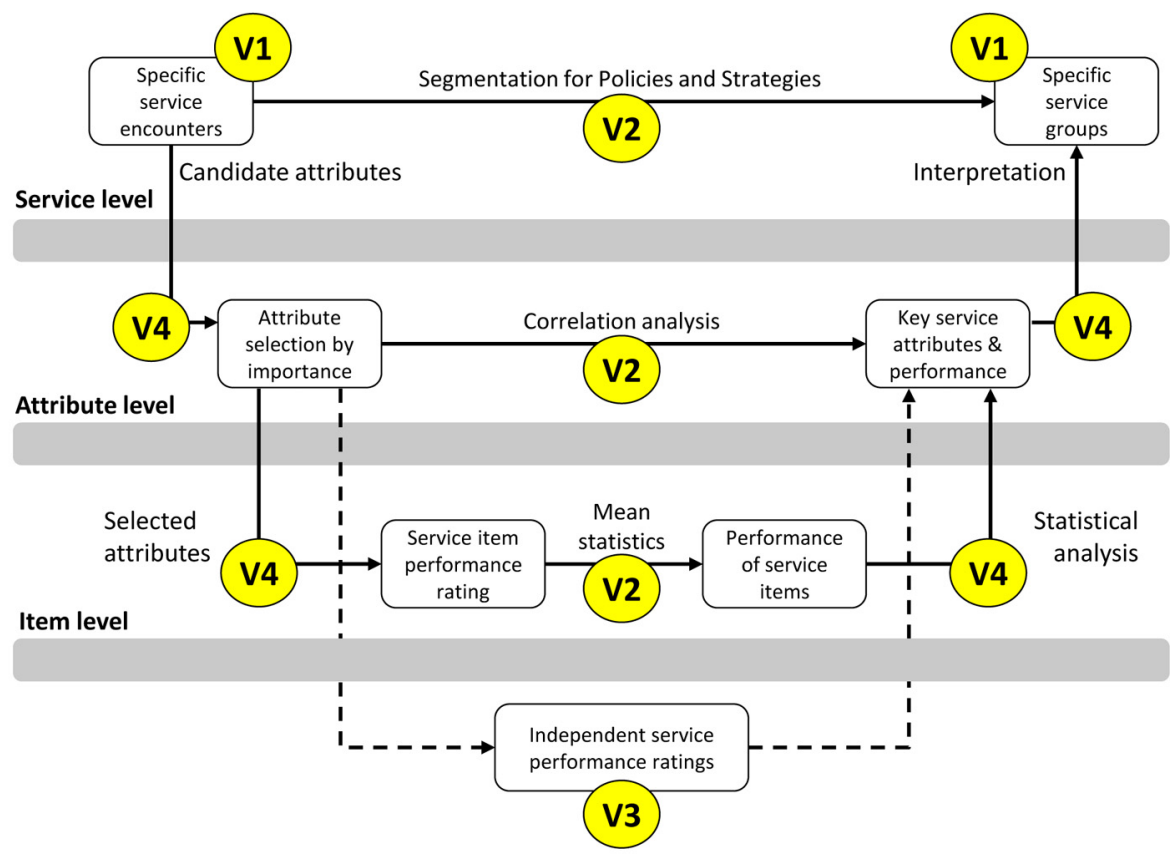

Source: The authors. The 'V-numbers' relate to the notes that follow

Figure 2. The VMSQ 
EJM

$51,5 / 6$

930

On the analytical side the process is mirrored through the use of statistical techniques to:

- select service groups;

- identify key service attributes (KSAs);

- assess the recorded performance at the level of the attributes; and

- (finally) assess the performance of the underlying service items.

The purpose of the progressive filtering is to minimise the presence of noise in the data and results, and to allow freedom to navigate patterns of perception in different service encounters (and the related patterns of management action that are required) within a structure that ensures completeness and cohesion.

\section{Deployment of the V-model of service quality model}

The deployment of the model follows the establishment of the attributes and collects and analyses data. We suggest that PCT and Repertory Grid (RepGrid) are suitable tools to be used with the VMSQ, as the associated assumptions and procedures (in particular the selection and scoring of constructs and attributes) align with the self-selection and rating of attributes in the VMSQ. Factor analysis used on its own can lead to the deletion of necessary attributes (Gilmore and McMullan, 2009). Having established a complete set of attributes, they can then be operationalised in a study using the VMSQ as the foundation for the design of the process. In four stages, the selection of attributes is validated and data are collected, as described in Table I:

The illustrative survey presented next followed this sequence.

\section{Testing the V-model of service quality in a multi-sector survey in Namibia}

Namibia is a country in southwest Africa bordering South Africa, Botswana, Zimbabwe and Angola. It has a sparse population of about 2,212,000, spread over $824,292 \mathrm{sq} \mathrm{km}$ - about the same size as France and Germany combined, or about half the size of Alaska (Central Intelligence Agency, 2015). Namibia has a long history of colonisation and conflict, which ended in 1990 when the country gained independence from apartheid South Africa. One of the legacies of the apartheid era is a heavily polarised dual economy. Twenty-five years after independence, the bulk of the country's wealth is still concentrated in the hands of the white minority, with more than 60 per cent of the black majority living near or below the poverty line.

The Government of the Republic of Namibia has struggled since independence to roll out basic services such as housing, water, sewerage and electricity to the majority of the

\section{Stage 1}

Stage 2

Stage 3

Table I.

The stages of VMSQ deployment

Stage 4
Pre-VMSQ theory building-build a survey instrument to measure service in a range of service sectors, based on a chosen theoretical design and attribute elicitation process. Test and review the chosen service quality attributes ("dimensions", in PBZ terminology), for example by means of workshops and focus groups

VMSQ data collection - Launch data collection, including the independent success ratings as well as attribute ratings

VMSQ data analysis - Analyse data at three levels: service groups, service success and service measurement VMSQ reporting - Report results at three levels: service group policy recommendations, service management procedures and service measurement practice 
populace. Along with the challenges relating to governance, logistics and resource distribution, it is clear that one reason for the lack of progress in basic service delivery is the absence of a service quality culture (Fjeldstad et al., 2005). This is the justification for the present study.

\section{The study}

This large multi-sector study elicited data from respondents, at their homes, as consumers of public services or customers of business service organisations in Namibia. Respondents had considerable flexibility in their choice of service and in their choice of significant attributes, making it an important indicator of consumer- and customer-driven concerns, needs, expectations and experiences.

The study had three objectives:

(1) to understand the drivers of service quality in a range of sectors in Namibia;

(2) to measure levels of service quality in those sectors; and

(3) to provide a diagnostic tool for improving service quality.

In this paper, the study is used to illustrate how the VMSQ can be used to assess service management on a large scale, in different sectors, at different levels and with different kinds of respondent; the paper does not attempt to report the full results of the study.

The 12 industry sectors within which data were collected are given in Table II.

This selection of industries includes commercial and government sectors representing areas where the majority of households in Namibia spend their time and money.

\section{Execution of the study}

Stage 1 - building the survey instrument and choose attributes. The first step was to decide on the service attributes to be employed. Along the "theory building" lines already discussed above, the options were:

- work from first principles using RepGrid analysis to identify candidate attributes of service quality (Kelly, 1970);

- $\quad$ start with the ten attributes first identified by Parasuraman et al. (1985);

- start with a more specialised set of attributes taken from other work, such as previous work by the author (Whyte and Bytheway, 1996); and

- establish "mathematical constructs" by means of statistical factor analysis.

The second option was chosen. While the first option might be preferred in more exploratory cases, in this case, time constraints made this impractical: the academic aim of the research was to exercise and operationalise the VMSQ as a new way of achieving service quality measurement rather than to develop new attributes[2]. The third option risked that specialisation might render the attributes inappropriate in the present context, and the fourth carried the risk that statistical methods might exclude significant attributes. The second option provided generic attributes derived from a qualitative elicitation processes

Supermarkets

Municipal services

Telecommunications

Insurance services
Banks

Energy services

Security services

Post office services
Health services

Transport services

Home affairs

Education services
V-model of service quality

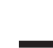


EJM

$51,5 / 6$

932

(interviews and focus groups) and positioned alongside many other studies using the PBZ attributes (Getty and Getty, 2003).

The ten PBZ attributes provided a start point for this study, but they proved not sufficient as the field work began. Initial validation meetings with individual stakeholders (including the office of the Prime Minister, a bank, a national newspaper, the national broadcaster and two consumer advocacy groups) reinforced the problems of poor service delivery and the need for service management, and also provided recurring anecdotal evidence for one additional attribute: the idea of Recovery. Many reports indicated that accessing service (from government departments in particular) requires correction of previous errors or misinformation. There is evidence of this elsewhere: Johnson and Mathews (1997) have argued for the inclusion of Recovery as a salient attribute of service quality. Recovery was therefore included as an eleventh attribute, knowing that if the anecdotal evidence was wrong, then the VMSQ survey process would make that clear. As it turned out, Recovery featured very strongly across almost every industry sector, supporting the idea that the ten PBZ attributes are not sufficient to explain all variations in service quality, in all circumstances. The study therefore proceeded with the 11 attributes listed in Table III.

Stage 2 -data collection process. A professional market research company was engaged to conduct interviews in people's homes, and 1,500 homes were visited over a three-month period. The sample was selected so as to be representative of the demographics in Namibia, thereby providing evidence from a variety of different segments.

During interviews (Figure 3, where "S" numbers refer to points on the diagram):

- S1: Respondents completed a map of services, indicating the range of services used in the last six months. Respondents were then requested to select a specific service to discuss in detail.

- S2: The list of 11 service quality attributes were then presented to respondents, who were directed to select five service attributes that, in their opinion, are most important for the delivery of the selected service.

\footnotetext{
1 Competence

Service employees are competent: possessing the required skills and knowledge to provide the service

2 Courtesy

Service employees are courteous: polite, respectful, considerate and friendly

3 Credibility

4 Security

5 Access

6 Communication

7 Customer knowledge The service knows its customers: an effort is made to understand the towards customers The service is credible: trustworthy and honest, having the best interests of the customer at heart

The service is secure: making the customer feel safe and free from danger

The service is accessible: it is approachable and easy to make contact with

The service communicates: it keeps customers informed in a language they understand and listens to them customer's needs

8 Tangibles

Tangibles of the service: the physical appearance and physical features are attractive

9 Reliability

10 Responsiveness

The service is reliable: it is consistent and dependable

Service employees are responsive: employees are willing and ready to provide the service and do so in a timely way

11 Recovery

The service recovers: there is quick and effective recovery from situations where the service fails or customers complain
}

Table III.

Source: Parasuraman et al. (1985) and authors 


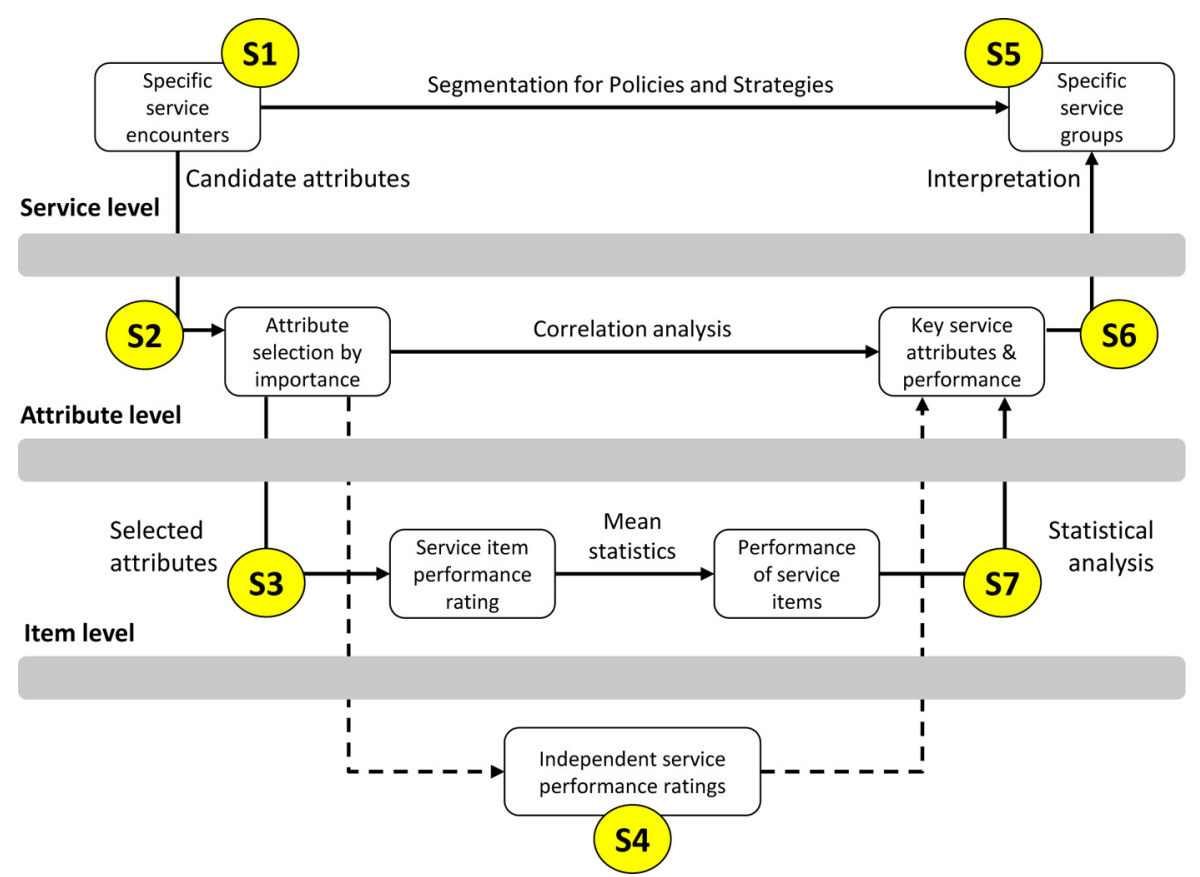

V-model of
service quality

933

- S3: Using a seven-point Likert scale, respondents then rated the performance of the service against the underlying items of the five of attributes they selected.

- S4: Finally, respondents were asked to rate the overall performance of the service to provide an independent rating.

For subsequent services the process was repeated from S2.

This procedure recognises that when people are faced with complex decisions, they seek to simplify them by building manageable constructs based on five to seven variables (Kelly, 1955; Miller, 1956; Mandler et al., 1967). This approach reduces the likelihood of respondents answering questions which they feel are relatively unimportant or irrelevant, which is a potential issue with fixed questionnaires. If, on average, respondents to a fixed questionnaire felt that half of the attributes were unimportant to them, then half of the data would be clouded by statistical noise.

Stage 3 - data analysis. As indicated earlier, the analysis process introduces another series of filters that complements the steps in VMSQ data collection (see Figure 3 above):

- S5: The data collected is segmented or grouped into similar service groups for analysis (S5). For instance, all bank data are selected and analysed together or all services in a particular region may be analysed together.

- S6: Responses are analysed using Pearson's correlation analysis (S6). Selected attributes (S2) are correlated with respondent's overall rating for the service (S4). This gives an overall correlation coefficient for each attribute. The higher the coefficient, the greater importance an attribute plays in determining the quality of the service; those attributes with the higher correlation coefficients (at significance levels of 95 or 99 per 
EJM

$51,5 / 6$

cent) are termed KSAs. Attributes that have low significance levels are not designated as KSAs.

Having determined KSAs, the mean for each is calculated to determine how well the service performs for that particular attribute (S6). A low mean score suggests that though an attribute is important to respondents, the service performs poorly against it and therefore becomes a focus for remedial attention.

- S7: Drilling down, service items are inspected for all KSAs, and the mean calculated to determine service performance at item level (S7). Low performing items indicate specific areas in the service requiring attention.

Stage 4-reporting of results. The intention here is to illustrate the types of results reported by the VMSQ, how these results are useful to stakeholders and how they differ from other approaches such as SERVQUAL. Results are reported at the three levels established in the model: the Service Level, the Attribute Level and the Item Level (as illustrated in Figure 2).

The following discussion illustrates the use of the VMSQ model by reference to a selection of the available reports that are available at the levels of service, attribute and item. Working at three different levels provides advantages to managers that are striving to manage service delivery more effectively because at each level, there are different possibilities:

- At the Service Level, it is possible to segment the data in different ways, by type of industry (e.g. Government departments), by type of respondent (e.g. residents of a particular region) or by type of service (e.g. retail services). In the examples that follow, industry sector is used to illustrate analysis at this high level.

- At the Attribute Level, the configuration of KSAs will be different for different service groups, e.g. you would expect Security to feature as a KSA for banks but not necessarily for supermarkets. The performance of KSAs whether strong or poor, provide service managers with an indication where to focus their attention, e.g. low ratings for security for a bank should certainly be setting-off alarm bells.

- At the Item Level for KSAs, relatively low mean values point to specific issues requiring attention.

The sections that follow now present selected data at these three different levels, not to tell a specific story but rather to show the scope and flexibility of analysis that is available. The tables are illustrative rather than definitive, but are based on 7,258 responses on customer perceptions of service quality.

\section{Service level reports}

Frequency of responses by industry. Table IV lists the breakdown of frequencies by industry. This is standard information produced by most surveys. Because respondents chose the service according to their interests, the list gives an indication of the services uppermost in the minds of the Namibian public.

Overall performance by service or industry. At the service level, a comparative performance score is calculated for each service. This is achieved by taking the definition of each of the 11 service quality attributes, presenting them in a Likert scale table and asking every respondent to rate how well the service is performed for each criterion. The final score for each respondent was a simple mean of the 11 responses.

Results of the comparative analysis are given in Figure 4. The first row shows the global results for all responses, including frequency (the number of responses), the mean of Likert scale ratings scored on a Likert scale of 1 to 5 and the same mean converted to a percentage. 


\begin{tabular}{lrrrr}
\hline Sector & Frequency & & $\begin{array}{r}\text { V-model of } \\
\text { Supermarkets }\end{array}$ & $\begin{array}{r}(\%) \\
\text { service quality }\end{array}$ \\
Banks & 1,103 & 15.2 & \\
Transport & 994 & 13.7 & \\
Telecommunications & 910 & 9.5 & \\
Security services & 666 & 9.0 & $\mathbf{9 3 5}$ \\
Health services & 650 & 8.8 & \\
Insurance services & 638 & 6.5 & \\
Energy services & 472 & 5.4 & \\
Education services & 461 & 5.0 & Table IV. \\
Municipal services & 389 & 4.7 & Distribution of \\
Home affairs & 364 & 3.7 & responses by service \\
Post office services & 342 & 100.0 & industry \\
Total & 269 & & & \\
\end{tabular}

Based on past experience, the percentage scale is seen at three levels: low (0-64 per cent), average (65-74 per cent) and high (75 per cent+). This "levelling" is subjective at this stage, but it will become more trustworthy over time when trends are identified. It does allow the identification of groups: Insurance is the only "high-rated" group; a range of sectors are found to be "average" (banks, post office, telecommunications, energy, supermarkets, education, health and security); specific government services are found to be "low-rated" (municipal services, home affairs together with transport). Of course, there were variations within these groups. The Roman Catholic Hospital in Windhoek scored 88 per cent on the service quality index, and yet, it belongs to a sector - health services - that ranked eighth overall with an average of only 65 per cent. This highlights the need to be able to navigate through the data without constraint and to identify where there are such differences, to gain a complete understanding.

\begin{tabular}{|c|l|c|c|c|}
\hline Ranking & Sector & $\begin{array}{c}\text { Freq } \\
\text { N }\end{array}$ & Mean & $\begin{array}{c}\text { Performance } \\
\text { Percentage }\end{array}$ \\
\hline & Global Analysis (total) & 7258 & 3.7302 & $68 \%$ \\
\hline 1. & Insurance Services & 472 & 4.0822 & $77 \%$ \\
\hline 2. & Banks & 994 & 3.9778 & $74 \%$ \\
\hline 3. & Post Office Services & 269 & 3.9770 & $74 \%$ \\
\hline 4. & Telecommunications & 666 & 3.9525 & $74 \%$ \\
\hline 5. & Energy Services & 461 & 3.8872 & $72 \%$ \\
\hline 6. & Supermarkets & 1103 & 3.8046 & $70 \%$ \\
\hline 7. & Education Services & 389 & 3.7752 & $69 \%$ \\
\hline 8. & Health Services & 638 & 3.6039 & $65 \%$ \\
\hline 9. & Security Services & 650 & 3.5992 & $65 \%$ \\
\hline 10. & Municipal Services & 364 & 3.4718 & $62 \%$ \\
\hline 11. & Home Affairs & 342 & 3.3262 & $58 \%$ \\
\hline 12. & Transport & 910 & 3.2897 & $57 \%$ \\
\hline & & & & \\
\hline
\end{tabular}

Figure 4.

Sector (or industry) ranked by comparative performance ratings 
EJM

$51,5 / 6$

936

The overall level of service quality for all 12 sectors is 68 per cent, suggesting that the "average" group could be divided into two parts or that the "levels" adopted could be revised. This result was considered by local commentators to be quite high for Namibia, but comparison with other countries cannot yet be undertaken because methods are known to vary. For example, the UK Institute of Customer Service found that the aggregate UK Satisfaction Index in January 2016 was 77 per cent, but it is not calculated in the same way.

\section{Attribute level reports}

Banking sector report. Although it has been chosen only for the purposes of illustration, the banking sector does have a high level of response $(\mathrm{N}=994)$, and in terms of performance, it is second only to the insurance sector. The choice of the banking sector as an illustration was not influenced by academic consideration but rather by local interest in Namibia. For example, the results for other sectors were typically "as expected", but the results from the banks were more surprising and therefore interesting. The purpose here is to illustrate results at the attribute level, as shown in Figure 5.

These results raise some noteworthy observations:

- For the banking sector as a whole, KSAs which are drivers of service quality in this sector have correlations of over 0.6 (60 per cent). Responsiveness to Credibility are the relevant attributes and are significant to 0.001 or 99 per cent confidence levels. The correlation represents the level of importance the attribute has on the customer's perception of service quality. Security and Tangibles scored correlations of 48 and 46 per cent, respectively, and correspondingly are less important overall. These metrics are a direct result of the VMSQ allowing respondents to select attributes and then validating this selection through correlation analysis. Although in later versions of SERVQUAL, respondents are encouraged to apply weightings to attributes (Landrum et al., 2009), respondents still answer all questions and the assumption of homogeneity

Figure 5.

KSAs for the banking sector (sorted by correlation)

\begin{tabular}{|l|c|c|c|c|}
\hline Banking Sector (N=994) & $\mathrm{N}$ & Mean & Corr & Perf \\
\hline Responsiveness & 225 & 5.5680 & .692 & $76 \%$ \\
\hline Reliability & 361 & 5.5141 & .679 & $75 \%$ \\
\hline Recovery & 201 & 5.0746 & .662 & $68 \%$ \\
\hline Competence & 621 & 5.7304 & .661 & $79 \%$ \\
\hline Courtesy & 611 & 5.5450 & .638 & $76 \%$ \\
\hline Credibility & 502 & 5.5822 & .635 & $76 \%$ \\
\hline Customer Knowledge & 435 & 5.5563 & .592 & $76 \%$ \\
\hline Communication & 575 & 5.6887 & .569 & $78 \%$ \\
\hline Access & 564 & 5.5394 & .564 & $76 \%$ \\
\hline Security & 616 & 5.7675 & .485 & $79 \%$ \\
\hline Tangibles & 242 & 5.8727 & .463 & $81 \%$ \\
\hline
\end{tabular}

Notes: Red denotes poor performance and green positive performance; no colour average performance 
still applies. In the VMSQ, respondents complete an individualised questionnaire, and there is no equivalent process within SERVQUAL.

- Security was selected by 616 respondents as being of key importance; yet, this seems to be at odds with their overall rating for service importance (0.485). Possible reasons for this are that it is a hygiene factor, so its presence does not influence customer perception as much as its absence or there are conflicting sub-groups present in the Security attribute. The performance score for Security (79 per cent) is quite high, as one would expect for banks.

- Mean scores are converted into percentages shown in the performance (Perf) column, denoting how well banks performed overall for the service quality attribute. Interestingly, in Tangibles, banks are perceived to perform excellently, but the low correlation tells us this attribute is not a differentiator (a KSA) when it comes to service quality. Therefore, investing heavily in this area to change customer perceptions is going to be a sub-optimal use of financial and other resources.

- Recovery (refer to the earlier discussion for its origin) is a KSA for the banking sector, ranking number three, with a correlation (or importance score) of 0.662 , suggesting this attribute explains 66 per cent of the variability in service quality. The implication is that bank processes are not as transparent as they should be in this developing country.

Reporting on one bank. The banking data were analysed for each bank. Figure 6 presents the results for one such bank.

Observations similar to those made at the sector level can be made here, but in addition:

- The top five KSAs for this bank are present in the top group for the sector, but the reverse is not true: Recovery here is far lower in the table than in the banking sector results.

- Recovery has a low comparative frequency and lower importance (correlation) rating for this bank because their service processes are well designed and communicated to their

\begin{tabular}{|l|c|c|c|c|}
\hline Bank (N=487) & $\mathrm{N}$ & Mean & Corr & Perf \\
\hline Responsiveness & 114 & 5.5807 & 0.743 & $76 \%$ \\
\hline Courtesy & 295 & 5.5688 & 0.690 & $76 \%$ \\
\hline Reliability & 170 & 5.6494 & 0.683 & $77 \%$ \\
\hline Competence & 316 & 5.7943 & 0.675 & $80 \%$ \\
\hline Credibility & 251 & 5.6195 & 0.644 & $77 \%$ \\
\hline Access & 255 & 5.5396 & 0.641 & $76 \%$ \\
\hline Recovery & 89 & 5.1056 & 0.636 & $68 \%$ \\
\hline Communication & 298 & 5.7698 & 0.561 & $79 \%$ \\
\hline Tangibles & 119 & 5.9429 & 0.551 & $82 \%$ \\
\hline Customer Knowledge & 216 & 5.5463 & 0.534 & $76 \%$ \\
\hline Security & 307 & 5.7251 & 0.494 & $79 \%$ \\
\hline
\end{tabular}

Notes: Red denotes poor performance and green positive performance; no colour average performance

Figure 6.

KSAs for the bank (sorted by correlation) 
EJM

$51,5 / 6$

938

Figure 7.

Reporting on Recovery items for the bank customers. In the large branches, customers do not need to rely on certain individuals in the bank to get things done. However, the presence of the Recovery rating (at position number seven) suggests that in the smaller rural branches, customers still have to rely on recovery procedures to get service, and the flexibility of the VMSQ allowed this to be easily verified. The performance rating suggests that when things do go wrong, customers are likely to get it sorted to their satisfaction in 68 per cent of the cases, not a particularly strong result for one of the largest retail banks in Namibia.

- The emphasis on Responsiveness, Courtesy and Competence of staff reflect the culture of this bank and what is important to the organisation. This is particularly reflected in service quality performance scores, e.g. Staff Competence is rated at 80 per cent, one of the highest across all the attributes. This is another important feature of the VMSQ; the pattern of KSAs reflect the dominant cultural characteristics of the organisation or sector, and this was also reported in an early study (Whyte, 1994).

\section{Item level reports}

The recovery attribute and its items. Drilling down to the lowest level of detail brings us to analysis by service item level. Here, service items can be reported with the service quality attribute (Figure 7). For example:

$$
\text { Mean }(\text { Recovery })=\text { Sum of means }(\text { Recovery Item } 1+\text { item } 2+\ldots \text { item } 5)
$$

This relationship between attributes and items is quite standard. The interesting point here is that in the VMSQ 89 of all respondents referring to this bank selected Recovery as one of their five most important attributes for service quality success. Looked at in another way, approximately 18 per cent of the bank's customers feel that some form of Recovery process is important for obtaining services from the bank. This result in itself may be quite disturbing news for such an established bank.

Item level analysis and reporting gives service managers an indication of where the key areas of strength (or weakness) lie within the service operation, as perceived by customers. Strengths can be leveraged to make improvements elsewhere in the service; weaknesses require remedial actions. For example, service item number five (5), "The organisation/ business compensates the customer for any inconvenience they suffer due to service

\begin{tabular}{|l|l|l|l|l|}
\hline Item & Statement & N & Mean & Perf \\
\hline Recovery & $\begin{array}{l}\text { The service recovers - quickly and effectively from } \\
\text { situations where the service fails or customers complain }\end{array}$ & 89 & 5.1056 & $68 \%$ \\
\hline Item-1 & & & & \\
\hline Item-2 & $\begin{array}{l}\text { When customers have a complaint/problem, the } \\
\text { employees show sincere interest in solving it }\end{array}$ & 89 & 5.461 & $74 \%$ \\
\hline Item-3 & $\begin{array}{l}\text { The organisation/business encourages their customers } \\
\text { to complain }\end{array}$ & 89 & 5.045 & $67 \%$ \\
\hline Item-4 & $\begin{array}{l}\text { The organisation/business makes it easy for customers } \\
\text { to complain }\end{array}$ & 89 & 5.045 & $67 \%$ \\
\hline Item-5 & $\begin{array}{l}\text { The organisation/business spots and acts on service } \\
\text { problems without waiting for complaints }\end{array}$ & 89 & 5.112 & $69 \%$ \\
\hline $\begin{array}{l}\text { The organisation/business compensates the customer } \\
\text { for any inconvenience they suffer due to service } \\
\text { problems }\end{array}$ & 89 & 4.865 & $64 \%$ \\
\hline
\end{tabular}

Note: Red is poor performance 
problems' is an assessment of service compensation practice". The bank was rated at 64 per cent for this item, which we flag as a red area, something requiring remedial action.

Though ratings at service item level are very informative and useful, we believe the most useful diagnostic information is derived at the KSA level, not the service item level. Service items can only be illustrative of what is happening at the service attribute level; they can never wholly explain a KSA. If customers select Reliability as one of their five most important attributes, they could be responding to reliability in the context of communication received or reliability of service staff or reliability of service machinery or even something else. Items associated with this service attribute will not cover the range of possible interpretations for every service context. Obviously, the more thorough the initial elicitation process, the better items will be a measure of attributes. However, we argue that service managers need to focus on the service attribute, not the items, and intelligently apply a range of remedial actions to improve its performance by empathising with the customer rather than relying mechanistically on the results from service items.

Outcome of the multi-sector test survey. This research set out to do the following:

- Understand the drivers of service quality in a range of service sectors in Namibia: KSAs were identified for 12 sectors within industry and government, providing a map that enables managers in those sectors to understand and control the level of quality perceived by recipients of those services.

- Provide measures of service quality: The research has provided valid and reliable measures of service quality for both diagnostic and comparative purposes.

- Provide a diagnostic tool for improving service quality: The VMSQ has been demonstrated to be a robust and adaptable tool for diagnosing and improving service quality at different levels, based on complex datasets and multiple contextual variables.

\section{Discussion and conclusions}

In this paper, we have discussed in some detail the application of the VMSQ as an approach which borrows precepts from PCT and the RepGrid, and extends them beyond the confines of data elicitation and construct building - typically seen as the principal purpose of RepGrid - to the operationalisation of those constructs in active service quality measurement.

\section{Capability of the V-model of service quality}

In the way that it elicits and manages data from respondents, the conceptualisation of the VMSQ is grounded in Kelly's PCT and RepGrid. This brings a level of sensitivity to the context of a particular study that is simply not possible with fixed survey instruments.

A general model. Though the VMSQ is modelled on RepGrid, it is a model that can be generalised and applied to other constructs of service quality, as has been done here. Any legitimate taxonomy of KSAs could be operationalised by using the VMSQ, with the advantage that it preserves customer heterogeneity by creating an adaptive questionnaire based on customers' individual perspectives, and yet correlates the data so as to reveal shared experiences among customers.

Requisite variety. As noted in earlier work (Whyte, 1994; Whyte et al., 1997), service management is a two-sided affair. At the level of this study - sampling on a national basis providers can be categorised according to service performance, but service recipients can also be categorised according to their characteristics and differences. Hence, the idea of service "segments" that the VMSQ reveals, each being a combination of a kind of service provider and a kind of consumer. This study has focused on the former (service providers), but it has delivered extensive data about the latter (service recipients). Future papers will go deeper into issues of segmentation based upon these data. 
EJM

$51,5 / 6$

940

The volume and variety of service management data that will become available are going to extend considerably. It is not true that a singular approach to service management will necessarily lead to an adequate understanding, it is important to understand the characteristics of an organisation as well as of its customers, and to make the best possible use of the data that are available. Although this work focused on the views of individuals about service providers, it has shown that there is an aggregate view at a higher level, and at the same time, there is detail at lower levels, providing both aggregate and detailed views. If this is recognised by service providers and sector leaders, it will lead to a greatly enhanced probability of perceived and actual service success.

Selectable attributes. Where the theory building process leaves researchers with a large number of attributes (10 or more), the tendency in service quality research has been to apply a reduction technique like factor analysis to reduce the number of attribute. With the VMSQ, this no longer needs to be the case as the instrument can successfully accommodate these large attribute lists. Research based upon the VMSQ is more likely to be representative of a wider number of services and to better reflect the complexity inherent in the service quality concept.

Importance rather than expectation. In the VMSQ, importance is used as a surrogate for expectation. It was found in Namibia that there is such a wide disparity between the lifestyles of the poor (the majority of the population) and the middle class that many of the respondents were unable to articulate their expectations of service, but could make a judgment about what was important for the successful delivery of that service. The expectations notion was too subjective and outside the "range of convenience" of many respondents, whereas the importance judgement was understood and was seen by them to be objective.

Reporting at different levels. Finally, the VMSQ provides a richer source of reporting at different levels, as illustrated in Figure 2. From a single study, the researcher is able to report at three complementary levels, drilling down into greater levels of detail where needed:

(1) At the highest level, reporting is by service scenario or service group; here, the statistical results are rendered appropriate for comparative benchmarking, or for individual organisational diagnostics.

(2) The next level is the attribute level, arguably producing the most important statistics in the VMSQ. Here, specific service quality attributes are selected by respondents on the basis of importance and are then correlated with the respondent's independent rating of service quality to identify KSAs. KSAs are those attributes that explain most of the customers' perceptions of service quality variability. They are also the attributes that are likely (if well managed) to have the biggest impact on customers' perceptions of the service.

(3) Service items, seen at the level of the mean, identify the performance of specific aspects of the service attribute. However, these items are only indicators or examples; individually, they are not comprehensive measures of the service attribute. The whole is greater than the sum of the parts: a poor score at the item level (such as "The organisation/business is conveniently located") should be a concern to management, but the "parent" attribute to which this statement belongs ("Access", in this case) should be of greater concern.

\section{Summary of research outcomes}

The V-model of customer service is a method that has appeal for both practitioners and researchers.

- It builds on existing theory from service quality (SERVQUAL) and good information systems development practice (the V-Model of systems development). 
- The VMSQ extends the identification of attributes to the operationalisation of service quality.

- The VMSQ has already been successfully used as a consultancy tool to diagnose issues in service quality and recommend improvements.

- The VMSQ can be automated as a computer program with the ability to provide simple visualisation of complex data analyses.

- An underlying assumption of the VMSQ is the complexity of service quality management. This issue of complexity and variety needs to be investigated further.

- In this study, the ten attributes (or "dimensions", in PBZ terms) of service quality developed by Parasuraman and colleagues were used as a starting point. However, the discovery of an additional attribute, Recovery, suggests that further work is needed to identify a more comprehensive range of attributes. RepGrid is an appropriate methodology for further work, as it brings in useful theory from psychology, and there is experience of its use in studies related to service quality management (Whyte, 1994; Bytheway, 2016).

\section{Contribution to practice and further development}

This paper has explained the four-stage sequence that is recommended for deployment and operationalisation of the VMSQ. Experience will develop this understanding and make clearer how candidate attributes might best be selected and then validated, and what refinements will allow respondents to more easily provide the data that are needed. It is interesting that the study reported here took respondents to the limits of their "range of convenience"; the objective is to find ways in which more variety can be accommodated.

The VMSQ is a significant step forward from SERVQUAL and other approaches to service quality management. Other researchers are invited to take up the challenge to further investigate the application of VMSQ. A copy of the questionnaire that was used in the illustrative study is in the Appendix to this paper.

\section{Contribution to theory and further research}

The history of service management research is already long, and in some respects, it is somewhat tortured. A relatively simple idea (albeit with quite complex origins) SERVQUAL - has been adopted, adapted and challenged in ways that few other theories have enjoyed. However, the complexity of the phenomenon and the simplicity of much work around it has seriously limited what has been possible to achieve. Consumers and customers experience more new kinds of service than they do better kinds of service, especially as organisations have adopted mobile technologies that offer benefits even if at a cost. New technologies disrupt industries: they demand that consumers and customers learn and adopt new skills that are not always in place and lead to high levels of necessary support.

In a context such as this, the VMSQ takes the measurement and management of service quality forwards by providing additional flexibility in data collection and capability in data analysis. Further research will focus on dealing with the high volume and variety of data that becomes available in the future. Whether there is new theory to be found that will guide the ways that this is done remains to be seen. For the moment, the VMSQ has added important new theoretical components to a mix of tools and techniques that was not delivering what was needed.

\section{Final word}

This paper set out to present a new model for operationalising service quality measurement that is based on psychological theory, has methodological symmetry and reflects the 
EJM

$51,5 / 6$

942

inherent complexity of service quality management concepts. The VMSQ addresses all of these requirements and addresses many of the criticisms levelled at SERVQUAL and other service quality measurement methods. The illustrative survey of service quality in Namibia shows how detailed insight into service quality management can be gained at different levels, with symmetry, guided by the fundamental features of the VMSQ.

There is now good reason to return to Ondangwa and Outapi, to establish those socio-economic profiles and establish the measures that will tell government how the circumstances of communities might most effectively be improved. In Namibia as a whole, the VMSQ is already a vital part of a project to deliver service excellence.

\section{Notes}

1. Later in this paper, these "dimensions" will be referred to generically as "attributes".

2. Previous work by the authors has already demonstrated the use of RepGrid at the theory building stage (Whyte et al., 1997); further research can assess the merits of RepGrid in developing attributes from first principles in this new context.

\section{References}

Abdullah, F. (2006), "Measuring service quality in higher education: HEdPERF versus SERVPERF", Marketing Intelligence \& Planning, Vol. 24 No. 1, pp. 31-47.

Al-allak, B.A. and Ali Bekhet, H. (2011), "Beyond SERVQUAL: a paradigm shift", Australian Journal of Basic and Applied Sciences, Vol. 5 No. 7, pp. 129-134.

Augustyn, M.M. and Seakhoa-King, A. (2004), "Is the SERVQUAL scale an adequate measure of quality in leisure, tourism and hospitality", Advances in Hospitality and Leisure, Vol. 1, pp. 3-24.

Baobab (2013), "Growth and other good things", Economist, 1 May.

Bytheway, A. (2015), Investing in Information: The Information Management Body of Knowledge, Springer, Geneva, available at: www.springer.com/gp/book/9783319119083.

Bytheway, A. (2016), "The availability, applicability and utility of information systems engineering standards in South African higher education”, Doctoral thesis, University of the Western Cape, Bellville.

Carr, C.L. (2007), "The Fairserv model: consumer reactions to services based on a multidimensional evaluation of service fairness", Decision Sciences, Vol. 38 No. 1, pp. 107-130.

Ceipidor, U.B., Medaglia, C.M., Volpi, V., Moroni, A., Sposato, S. and Tamburrano, M. (2011), "Design and development of a social shopping experience in the IoT domain: the ShopLovers solution", 19th International Conference on Software, Telecommunications and Computer Networks (SoftCOM), Split, 15-17 September, IEEE, pp. 1-5.

Central Intelligence Agency (2015), The World Factbook 2014-15, Government Printing Office.

Dakora, E.A.N. and Bytheway, A. (2011), "Africa in the 21st century: an exploration of the Africanisation of South African retailing", Proceeding of 13th CODESRIA General Assembly, Rabat, Morocco.

Fick, D. (2007), Africa: Continent of Economic Opportunity, Real African Publishers.

Fjeldstad, O.-H., Geisler, G., Nangulah, S., Nygaard, K., Pomuti, A., Shifotoka, A. and Van Rooy, G. (2005), Local Governance, Urban Poverty and Service Delivery in Namibia, Chr. Michelsen Institute.

Getty, J.M. and Getty, R.L. (2003), "Lodging quality index (LQI): assessing customers' perceptions of quality delivery", International Journal of Contemporary Hospitality Management, Vol. 15 No. 2, pp. 94-104.

Gilmore, A. and McMullan, R. (2009), "Scales in services marketing research: a critique and way forward”, European Journal of Marketing, Vol. 43 Nos 5/6, pp. 640-651. 
Jara, A.J., Parra, M.C. and Skarmeta, A.F. (2012), "Marketing 4.0: a new value added to the marketing through the internet of things", Sixth International Conference on Innovative Mobile and Internet Services in Ubiquitous Computing (IMIS), Palermo, 4-6 July, IEEE, pp. 852-857.

Johnson, C. and Mathews, B.P. (1997), "The influence of experience on service expectations", International Journal of Service Industry Management, Vol. 8 No. 4, pp. 290-305.

Kelly, G.A. (1955), The Psychology of Personal Constructs, W.W. Norton \& Company, New York, NY.

Kelly, G.A. (1970), "A brief introduction to personal construct theory”, in Bannister, D. (Ed.), Perspectives in Personal Construct Theory, Academic Press, London, pp. 1-29.

Ladhari, R. (2009), "A review of twenty years of SERVQUAL research”, International Journal of Quality and Service Sciences, Vol. 1 No. 2, pp. 172-198.

Landrum, H., Prybutok, V., Zhang, X. and Peak, D. (2009), "Measuring IS system service quality with SERVQUAL: users' perceptions of relative importance of the five SERVPERF dimensions", Informing Science: The International Journal of an Emerging Transdiscipline, Vol. 12, pp. 17-35.

Mandler, G., Mussen, P. and Kogan, N. (1967), New directions in Psychology: III, Holt, Rinehart and Winston.

Miller, G.A. (1956), "The magical number seven, plus or minus two: some limits on our capacity for processing information", Psychological Review, Vol. 63 No. 2, p.81.

Mulemfo, M.M. (2000), Thabo Mbeki and the African Renaissance: The Emergence of a New African Leadership, Actua Press.

Parasuraman, A., Zeithaml, V.A. and Berry, L.L. (1985), “A conceptual model of service quality and its implications for future research", The Journal of Marketing, Vol. 49 No. 4, pp. 41-50.

Parasuraman, A., Zeithaml, V.A. and Berry, L.L. (1988), "SERVQUAL: a multiple-item scale for measuring consumer perceptions of service quality", Journal of retailing, Vol. 64 No. 1, pp. 12-40.

Stacey, C.S. and Bick, G. (2014), "Validating key customer service encounters across industries to align service delivery", Customer Service Management Africa, NUST, Windhoek.

Tate, M. and Evermann, J. (2010), “The end of ServQual in online services research: where to from here?”, e-Service Journal, Vol. 7 No. 1, pp. 60-85.

Wei, W. and Liping, L. (2013), "Research on the coupling relations between technology innovation and business modes innovation of IOT industry based on SD", 6th International Conference on Information Management, Innovation Management and Industrial Engineering (ICIII), Shannxi, 23-24 November, IEEE, pp. 66-69.

Whyte, G. (1994), "Understanding user perceptions of successful information systems", Doctoral thesis, Cranfield School of Management, Cranfield.

Whyte, G. and Bytheway, A. (1996), "Factors affecting information systems' success", International Journal of Service Industry Management, Vol. 7 No. 1, pp. 74-93.

Whyte, G., Bytheway, A. and Edwards, C. (1997), "Understanding user perceptions of information systems success", Journal of Strategic Information Systems, Vol. 6 No. 1, pp. 35-68.

Xu, L.D. (2011), "Information architecture for supply chain quality management”, International Journal of Production Research, Vol. 49 No. 1, pp. 183-198.

Zeithaml, V., Parasuraman, A. and Malhotra, A. (2002), "Service quality delivery through web sites: a critical review of extant knowledge", Journal of the Academy of Marketing Science, Vol. 30 No. 4, pp. 362-375.

\section{Corresponding author}

Grafton Whyte can be contacted at:drgwhyte@live.com 
EJM

$51,5 / 6$

\section{4}

Appendix. The VMSQ questionnaire

\begin{tabular}{|l|l|}
\hline Service category: & \\
\hline Name of organisation/business: & \\
\hline
\end{tabular}

\section{Service attributes}

From Show card - Please select 5 service attributes which are the most important and relevant to the service category you have just now chosen. Tick the appropriate columns.

\begin{tabular}{|c|c|c|c|c|c|c|c|c|c|c|}
\hline Competence & Courtesy & Credibility & Security & Access & $\begin{array}{c}\text { Communi } \\
\text { cation }\end{array}$ & $\begin{array}{c}\text { Customer } \\
\text { knowledge }\end{array}$ & Tangibles & Reliability & $\begin{array}{c}\text { Responsiv } \\
\text { eness }\end{array}$ & Recovery \\
\hline 1 & 2 & 3 & 4 & 5 & 6 & 7 & 8 & 9 & 10 & 11 \\
\hline
\end{tabular}

FW: only ask questions for the attributes chosen by the respondent!

\begin{tabular}{|c|c|c|c|c|c|c|c|c|}
\hline \multirow{6}{*}{ 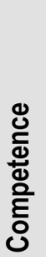 } & & $\begin{array}{l}\text { Strongly } \\
\text { disagree }\end{array}$ & & & & & & $\begin{array}{c}\text { Strongly } \\
\text { agree }\end{array}$ \\
\hline & $\begin{array}{l}\text { Employees of the organisation/business are knowledgeable about their } \\
\text { products and services }\end{array}$ & 1 & 2 & 3 & 4 & 5 & 6 & 7 \\
\hline & Employees provide correct and prompt replies on queries & 1 & 2 & 3 & 4 & 5 & 6 & 7 \\
\hline & Employees of the organisation/business come across as competent & 1 & 2 & 3 & 4 & 5 & 6 & 7 \\
\hline & $\begin{array}{l}\text { Employees of the organisation/business seem to have the skills necessary to } \\
\text { do the job }\end{array}$ & 1 & 2 & 3 & 4 & 5 & 6 & 7 \\
\hline & Managers of the organisation/business come across as competent & 1 & 2 & 3 & 4 & 5 & 6 & 7 \\
\hline
\end{tabular}

\begin{tabular}{|c|c|c|c|c|c|c|c|c|}
\hline \multirow{6}{*}{ 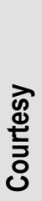 } & & $\begin{array}{l}\text { Strongly } \\
\text { disagree }\end{array}$ & & & & & & $\begin{array}{l}\text { Strongly } \\
\text { agree }\end{array}$ \\
\hline & Employees of the organisation/business are friendly and polite & 1 & 2 & 3 & 4 & 5 & 6 & 7 \\
\hline & $\begin{array}{l}\text { Employees of the organisation/business make appropriate eye contact and } \\
\text { pay attention to me during my interactions }\end{array}$ & 1 & 2 & 3 & 4 & 5 & 6 & 7 \\
\hline & Employees of the organisation/business treat customers with respect & 1 & 2 & 3 & 4 & 5 & 6 & 7 \\
\hline & The organisation/business values me as a client & 1 & 2 & 3 & 4 & 5 & 6 & 7 \\
\hline & The employees of the organisation/business are interested in helping me & 1 & 2 & 3 & 4 & 5 & 6 & 7 \\
\hline
\end{tabular}

\begin{tabular}{|c|c|c|c|c|c|c|c|c|}
\hline \multirow{6}{*}{$\begin{array}{l}\text { 壱 } \\
\text { 章 } \\
\text { 인 }\end{array}$} & & $\begin{array}{l}\text { Strongly } \\
\text { disagree }\end{array}$ & & & & & & $\begin{array}{c}\text { Strongly } \\
\text { agree }\end{array}$ \\
\hline & It is an organisation/business that I can trust & 1 & 2 & 3 & 4 & 5 & 6 & 7 \\
\hline & It is an organisation/business with a good reputation & 1 & 2 & 3 & 4 & 5 & 6 & 7 \\
\hline & It is an organisation/business that has customer's interest at heart & 1 & 2 & 3 & 4 & 5 & 6 & 7 \\
\hline & It is an organisation/business that behaves with honesty and integrity & 1 & 2 & 3 & 4 & 5 & 6 & 7 \\
\hline & & 1 & 2 & 3 & 4 & 5 & 6 & 7 \\
\hline
\end{tabular}

\begin{tabular}{|c|c|c|c|c|c|c|c|c|}
\hline \multirow{6}{*}{ 丰 } & & $\begin{array}{l}\text { Strongly } \\
\text { disagree }\end{array}$ & & & & & & $\begin{array}{c}\text { Strongly } \\
\text { agree }\end{array}$ \\
\hline & I feel safe in and around the organisation/business & 1 & 2 & 3 & 4 & 5 & 6 & 7 \\
\hline & The organisation/business has efficient security at their premises & 1 & 2 & 3 & 4 & 5 & 6 & 7 \\
\hline & When dealing with the organisation/business, I feel safe with their transactions & 1 & 2 & 3 & 4 & 5 & 6 & 7 \\
\hline & $\begin{array}{l}\text { The organisation/business has sufficient systems and controls in place to } \\
\text { ensure honesty and ethical behaviour of their employees }\end{array}$ & 1 & 2 & 3 & 4 & 5 & 6 & 7 \\
\hline & I feel my transactions with the organisation/business are kept confidential & 1 & 2 & 3 & 4 & 5 & 6 & 7 \\
\hline
\end{tabular}

\begin{tabular}{|c|c|c|c|c|c|c|c|c|}
\hline \multirow{6}{*}{ 号 } & & $\begin{array}{l}\text { Strongly } \\
\text { disagree }\end{array}$ & & & & & & $\begin{array}{c}\text { Strongly } \\
\text { agree }\end{array}$ \\
\hline & The organisation/business is conveniently located & 1 & 2 & 3 & 4 & 5 & 6 & 7 \\
\hline & The organisation/business is easily accessible & 1 & 2 & 3 & 4 & 5 & 6 & 7 \\
\hline & The organisation/business has operating hours convenient to me & 1 & 2 & 3 & 4 & 5 & 6 & 7 \\
\hline & $\begin{array}{l}\text { The service of the organisation/business is easily accessible by telephone } \\
\text { (lines are not too busy \& you are not put on hold for too long) }\end{array}$ & 1 & 2 & 3 & 4 & 5 & 6 & 7 \\
\hline & The waiting time to receive service is not extensive & 1 & 2 & 3 & 4 & 5 & 6 & 7 \\
\hline
\end{tabular}

(continued) 


\begin{tabular}{|c|c|c|c|c|c|c|c|c|}
\hline \multirow{6}{*}{ 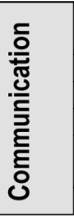 } & & $\begin{array}{l}\text { Strongly } \\
\text { disagree }\end{array}$ & & & & & & $\begin{array}{c}\text { Strongly } \\
\text { agree }\end{array}$ \\
\hline & The organisation/business keeps me informed in a language that I understand & 1 & 2 & 3 & 4 & 5 & 6 & 7 \\
\hline & The organisation/business listens to my needs and queries & 1 & 2 & 3 & 4 & 5 & 6 & 7 \\
\hline & The organisation/business provides professional advice if needed & 1 & 2 & 3 & 4 & 5 & 6 & 7 \\
\hline & $\begin{array}{l}\text { There is sufficient information available about the organisation/business' } \\
\text { services (brochures, internet etc.) }\end{array}$ & 1 & 2 & 3 & 4 & 5 & 6 & 7 \\
\hline & The organisation/business makes communication convenient for me & 1 & 2 & 3 & 4 & 5 & 6 & 7 \\
\hline \multirow{6}{*}{ 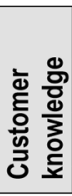 } & & $\begin{array}{l}\text { Strongly } \\
\text { disagree }\end{array}$ & & & & & & $\begin{array}{l}\text { Strongly } \\
\text { agree }\end{array}$ \\
\hline & The organisation/business understands my needs & 1 & 2 & 3 & 4 & 5 & 6 & 7 \\
\hline & The employees of the organisation/business give me personal attention & 1 & 2 & 3 & 4 & 5 & 6 & 7 \\
\hline & The employees of the organisation/business make an effort to get to know me & 1 & 2 & 3 & 4 & 5 & 6 & 7 \\
\hline & The organisation/business is adaptable to changing needs of their customers & 1 & 2 & 3 & 4 & 5 & 6 & 7 \\
\hline & The organisation/business instils confidence in customers & 1 & 2 & 3 & 4 & 5 & 6 & 7 \\
\hline \multirow{6}{*}{$\frac{\frac{9}{0}}{\frac{\overline{0}}{\tilde{ர}}}$} & & $\begin{array}{l}\text { Strongly } \\
\text { disagree }\end{array}$ & & & & & & $\begin{array}{l}\text { Strongly } \\
\text { agree }\end{array}$ \\
\hline & The physical facilities of the organisation/business are visually appealing & 1 & 2 & 3 & 4 & 5 & 6 & 7 \\
\hline & Employees are neatly dressed and present a positive image & 1 & 2 & 3 & 4 & 5 & 6 & 7 \\
\hline & $\begin{array}{l}\text { The tools and equipment to provide the services are clean and in a good } \\
\text { condition }\end{array}$ & 1 & 2 & 3 & 4 & 5 & 6 & 7 \\
\hline & $\begin{array}{l}\text { Material associated with the service (pamphlets/statement etc.) are appealing, } \\
\text { correct and in a good condition }\end{array}$ & 1 & 2 & 3 & 4 & 5 & 6 & 7 \\
\hline & The organisation/business has modern technology & 1 & 2 & 3 & 4 & 5 & 6 & 7 \\
\hline \multirow{6}{*}{ 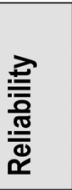 } & & $\begin{array}{l}\text { Strongly } \\
\text { disagree }\end{array}$ & & & & & & $\begin{array}{l}\text { Strongly } \\
\text { agree }\end{array}$ \\
\hline & The organisation/business gives prompt service to customers & 1 & 2 & 3 & 4 & 5 & 6 & 7 \\
\hline & When employees promise to do something by a certain time, they will do so & 1 & 2 & 3 & 4 & 5 & 6 & 7 \\
\hline & The quality of the products/services are consistently good & 1 & 2 & 3 & 4 & 5 & 6 & 7 \\
\hline & The organisation/business insists on error free records (incl. invoices/bills) & 1 & 2 & 3 & 4 & 5 & 6 & 7 \\
\hline & The organisation/business performs the services right the first time & 1 & 2 & 3 & 4 & 5 & 6 & 7 \\
\hline \multirow{6}{*}{ 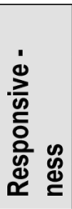 } & & $\begin{array}{l}\text { Strongly } \\
\text { disagree }\end{array}$ & & & & & & $\begin{array}{c}\text { Strongly } \\
\text { agree }\end{array}$ \\
\hline & The organisation/business gives prompt service & 1 & 2 & 3 & 4 & 5 & 6 & 7 \\
\hline & The employees are willing and enthusiastic to assist & 1 & 2 & 3 & 4 & 5 & 6 & 7 \\
\hline & The employees are never too busy to respond and assist & 1 & 2 & 3 & 4 & 5 & 6 & 7 \\
\hline & The employees will tell customers exactly when services will be performed & 1 & 2 & 3 & 4 & 5 & 6 & 7 \\
\hline & The employees give feedback/call back when required & 1 & 2 & 3 & 4 & 5 & 6 & 7 \\
\hline \multirow{6}{*}{ 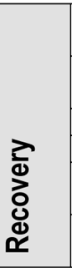 } & & $\begin{array}{l}\text { Strongly } \\
\text { disagree }\end{array}$ & & & & & & $\begin{array}{l}\text { Strongly } \\
\text { agree }\end{array}$ \\
\hline & $\begin{array}{l}\text { When customers have a complaint/problem, the employees shows sincere } \\
\text { interest in solving it }\end{array}$ & 1 & 2 & 3 & 4 & 5 & 6 & 7 \\
\hline & The organisation/business encourages their customers to complain & 1 & 2 & 3 & 4 & 5 & 6 & 7 \\
\hline & The organisation/business makes it easy for customers to complain & 1 & 2 & 3 & 4 & 5 & 6 & 7 \\
\hline & $\begin{array}{l}\text { The organisation/business spots and acts on service problem without waiting } \\
\text { for complaints }\end{array}$ & 1 & 2 & 3 & 4 & 5 & 6 & 7 \\
\hline & $\begin{array}{l}\text { The organisation/business compensates the customer for any inconvenience } \\
\text { they suffer due to service problems }\end{array}$ & 1 & 2 & 3 & 4 & 5 & 6 & 7 \\
\hline \multirow{2}{*}{$\begin{array}{l}\overline{\bar{\varpi}} \\
\stackrel{0}{0}\end{array}$} & & $\begin{array}{l}\text { Strongly } \\
\text { disagree }\end{array}$ & & & & & & $\begin{array}{c}\text { Strongly } \\
\text { agree }\end{array}$ \\
\hline & Overall, the service delivered by this organisation/business is of good quality & 1 & 2 & 3 & 4 & 5 & 6 & 7 \\
\hline
\end{tabular}

\section{V-model of} service quality 